\title{
COMPARISON OF ENERGY EFFICIENCY OF THE MUNICIPAL WASTE TREATMENT PLANT IN KRAKOW AND BIALYSTOK
}

\section{PORÓWNANIE EFEKTYWNOŚCI ENERGETYCZNE INSTALACJI TERMICZNEGO PRZETWARZANIA ODPADÓW KOMUNALNYCH W KRAKOWIE I BIALYMSTOKU}

\author{
DOI: $10.30540 /$ sae-2018-032
}

\begin{abstract}
A b stract
Thermal treatment of municipal waste is a method that has been rediscovered in Poland in recent years. National installations for thermal treatment of municipal waste launched in recent years draw on the experience of plants around the world and they use repeatedly proven technologies. Poland, within the framework of EU commitments, must reduce the amount of biodegradable waste going to landfills to 35\% by weight of the total municipal waste by July 16, 2020. Other biodegradable waste that can not be recycled should be subjected to biological or thermal decomposition. The purpose of this publication is to determine the efficiency of Polish installations for the thermal treatment of municipal waste, by comparing the energy efficiency ratio of installations in Krakow and Bialystok. These are two of the six installations of thermal waste treatment, which were created in 2015-2016. The Krakow incineration plant is the largest, and the Biatystok one of the smallest.
\end{abstract}

Keywords: combustion, energy recovery, municipal waste, energy efficiency coefficient

\section{Streszcze nie}

Termiczne przekształcanie odpadów komunalnych to metoda w Polsce na nowo odkryta w ostatnich latach. Krajowe instalacje termicznego przetwarzania odpadów komunalnych uruchamiane w ostatnich latach czerpia z doświadczeń zakładów na całym świecie $i$ stosuja wielokrotnie sprawdzone technologie. Polska, w ramach zobowiąań unijnych do 16 lipca 2020 roku musi ograniczyć ilość odpadów biodegradowalnych trafiajacych na składowiska do 35\% wagowo catkowitej masy odpadów komunalnych. Pozostałe odpady biodegradowalne, których nie można poddać recyklingowi powinny być poddane rozkładowi biologicznemu lub termicznemu. Celem niniejszej publikacji jest określenie efektywności polskich instalacji termicznego przekształcania odpadów komunalnych, poprzez porównanie współczynnika efektywności energetycznej instalacji w Krakowie oraz Białymstoku. Sa to dwie z sześciu instalacji termicznego przekształcania odpadów, które powstały w latach 2015-2016. Krakowska spalarnia jest największa, a białostocka jedna z najmniejszych.

Slowa kluczowe: spalanie, odzysk energii, odpady komunalne, współczynnik efektywności energetycznej

\section{INTRODUCTION}

In modern waste management, recovery has priority over disposal. Recovery means any process whose main objective is useful to employ waste by substituting other materials that would otherwise be used to fulfill a particular function, or waste being prepared to fulfill that function in the plant or in the economy. Waste neutralization is a non-recovery

\section{WPROWADZENIE}

We współczesnej gospodarce odpadami odzysk ma pierwszeństwo przed unieszkodliwianiem. Odzysk oznacza jakikolwiek proces, którego głównym celem jest użyteczne zastosowanie odpadów przez zastąpienie innych materiałów, które w przeciwnym przypadku zostałyby użyte do spełnienia danej funkcji, lub w wyniku którego odpady są przygotowywane do speł- 
process, even if the secondary effect of such a process is the recovery of a substance or energy [1]. In accordance with the Waste Directive 2008/98/ EC, the necessary condition for the inclusion of solid municipal waste in the recovery of R1, and not for the disposal of D10, is that the installation achieves the required value of the energy efficiency index [2].

The $\mathrm{R} 1$ recovery includes activities involving the use of waste mainly as a fuel or other means of generating energy, and the D10 process is thermal transformation on land [1]. For currently commissioned installations, the value of the energy efficiency coefficient can not be less than 0.65 [3]. According to literature data, new waste incineration plants obtain an energy efficiency ratio at the level of $0.75-1.2$, and modernized at 0,82 , such as, for example, the incineration plant in Brno.

A similar result should be expected from municipal waste incineration plants operated in Poland. Combustion of municipal waste can be carried out in fluidized bed boilers, stoker fired boilers or rotary kilns. Fluidised incineration plants, due to the necessity of shredding municipal waste causing significant consumption of electricity, have a lower energy efficiency coefficient of about 0.1 compared to burning in grate furnaces [4]. The literature shows that pyrolytic technology, gasification or plasma is not able to provide the required value of the energy efficiency index. It is assumed that in most cases it will be lower than 0.6. In the extreme case of Thermoselect technology, the energy efficiency ratio is approx. 0.3 [4].

The basic parameter determining the usefulness of matter for its use in the energy sector is the calorific value, which determines the fuel class. When producing formed fuels, whose heating value should be as high as possible, non-combustible ballast is removed, e.g. glass, ferrous and non-ferrous metals, ceramics. On the other hand, waste incinerated in installations for thermal treatment of municipal waste does not have to have specific calorific value, therefore ballast separation is not applied $[5,6]$.

The nominal calorific value accepted for incinerators in Poland ranges from 7.5 to $10.5 \mathrm{MJ} / \mathrm{kg}$. The nominal heating value of waste in Polish installations for thermal treatment of municipal waste is presented in Table 1. nienia takiej funkcji w danym zakładzie lub ogólnie $\mathrm{w}$ gospodarce. Unieszkodliwianie odpadów to proces niebędący odzyskiem, nawet jeżeli wtórnym skutkiem takiego procesu jest odzysk substancji lub energii [1]. Zgodnie z Dyrektywą w sprawie odpadów 2008/98/EC warunkiem koniecznym zaliczenia spalania stałych odpadów komunalnych do procesów odzysku R1, a nie do unieszkodliwiania D10, jest osiągnięcie przez instalację wymaganej wartości wskaźnika efektywności energetycznej [2]. Odzysk R1 obejmuje działania polegające na wykorzystaniu odpadów głównie jako paliwa lub innego środka wytwarzania energii, a proces D10 to termiczne przekształcanie na lądzie [1]. Dla współcześnie oddawanych do eksploatacji instalacji wartość współczynnika efektywności energetycznej nie może być mniejsza niż 0,65 [3]. Zgodnie $z$ danymi literaturowymi nowe spalarnie odpadów uzyskują wskaźnik efektywności energetycznej na poziomie 0,75-1,2, a modernizowane na poziomie 0,82 , tak jak na przykład spalarnia w Brnie. Podobnego wyniku należy oczekiwać od spalarni odpadów komunalnych eksploatowanych w Polsce. Spalanie odpadów komunalnych może być realizowane w kotłach ze złożem fluidalnym, kotłach rusztowych lub piecach obrotowych. Spalarnie fluidalne, $\mathrm{z}$ uwagi na konieczność rozdrabiania odpadów komunalnych powodujące znaczne zużycie energii elektrycznej, mają współczynnik efektywności energetycznej niższy o ok. $0,1, \mathrm{w}$ porównaniu do spalania w piecach rusztowych [4]. Literatura przedmiotu wykazuje, że technologia pirolityczna, zgazowania czy też plazmowa nie jest w stanie zapewnić wymaganej wartości wskaźnika efektywności energetycznej. Przyjmuje się, że w większości przypadków będzie on niższy od 0,6 . W skrajnym przypadku jakim jest technologia Thermoselect, współczynnik efektywności energetycznej wynosi ok. 0,3 [4].

Podstawowym parametrem określającym przydatność materii do jej wykorzystania w energetyce jest wartość opałowa, która decyduje o klasie paliwa. Podczas wytwarzania paliw formowanych, których wartość opałowa powinna być jak najwyższa, usuwa się niepalny balast, np. szkło, metale żelazne i nieżelazne, ceramika. Natomiast odpady spalane w instalacjach termicznego przetwarzania odpadów komunalnych nie muszą posiadać określonej kaloryczności, dlatego nie stosuje się oddzielenia balastu $[5,6]$.

Nominalna wartość opałowa przyjęta dla spalarni w Polsce waha się w granicach od 7,5 MJ/kg do $10,5 \mathrm{MJ} / \mathrm{kg}$. Nominalną wartością opałową odpadów w polskich instalacjach termicznego przetwarzania odpadów komunalnych przedstawiono w tabeli 1 . 


\begin{tabular}{|l|c|}
\hline Installations of thermal treatment of municipal waste & $\begin{array}{c}\text { Nominal heating } \\
\text { value of waste } \\
{[\mathrm{MJ} / \mathrm{kg}]}\end{array}$ \\
\hline Municipal Waste Disposal Plant in Białystok & 7.5 \\
\hline Municipal Waste Thermal Treatment Plant in Bydgoszcz & 8.5 \\
\hline Municipal Waste Thermal Treatment Plant in Konin & 8.5 \\
\hline Thermal Waste Transformation Plant in Krakow & 8.8 \\
\hline $\begin{array}{l}\text { Installation of Thermal Transformation of Municipal } \\
\text { Waste in Poznań }\end{array}$ & 8.4 \\
\hline Thermal Waste Disposal Plant in Szczecin & 10.5 \\
\hline
\end{tabular}

An important parameter is the chlorine content in incinerated municipal waste.It determines the technological parameters of the combustion process. If the content of halogenated organic compounds is above $1 \%$, the process temperature must exceed $1100^{\circ} \mathrm{C}$. This may affect the need for additional fuel in the case of low calorific value of waste. Chlorine can corrode the plant by forming acidic compounds. Fluorine and sulfur compounds have similar properties $[8,9]$.

Other parameters that determine the technological processes in the thermal treatment plant are the ash composition. Alkali compounds contained in the ash, among others Sodium, potassium, magnesium and calcium may cause molten slag to stick to the metal elements of boiler heating installations, as well as sludge [8].

The waste incineration process, which does not require additional fuel to be introduced into the combustion chamber (so-called autothermal combustion), is possible when the percentage of moisture, flammable and non-flammable substances in the waste meets the criteria [9]:

- moisture content $<50 \%$,

- content of flammable parts $>25 \%$,

- non-combustible content $<60 \%$.

The purpose of this publication is to determine the energy efficiency of Polish installations for the thermal treatment of municipal waste by comparing the energy efficiency ratio of installations in Kraków and Bialystok. These are two of the six installations of thermal waste treatment, which were created in 2015-2016. The Krakow incineration plant is the largest, and the Białystok one of the smallest.
Table 1. Nominal heating values of municipal waste in Polish installations for thermal treatment of municipal waste (based on [7])

Tabela 1. Nominalne wartości opałowe odpadów komunalnych $w$ polskich instalacjach termicznego przetwarzania odpadów komunalnych (na podstawie [7])

Istotnym parametrem jest zawartość chloru w spalanych odpadach komunalnych. Decyduje on o parametrach technologicznych procesu spalania. W przypadku zawartości związków chlorowcoorganicznych powyżej $1 \%$ temperatura procesu musi przekraczać $1100^{\circ} \mathrm{C}$. Może to wpłynąć na konieczność stosowania dodatkowego paliwa w przypadku niskiej kaloryczności odpadów. Chlor może powodować korozję instalacji przez tworzenie kwaśnych związków. Podobne właściwości wykazują też związki fluoru i siarki $[8,9]$.

Innymi parametrami warunkującymi procesy technologiczne w zakładzie termicznej przeróbki odpadów jest skład popiołu. Zawarte w popiele związki alkaliczne, m.in. sodu, potasu, magnezu i wapnia, mogą powodować przyklejanie stopionego żużla do metalowych elementów instalacji grzewczych kotła, a także przyrastanie osadów [8].

Proces spalania odpadów, którego prowadzenie nie wymaga wprowadzenia do komory spalania dodatkowego paliwa wspomagającego (tzw. spalanie autotermiczne), możliwy jest, gdy procentowy udział wilgoci, substancji palnych i niepalnych w odpadach odpowiadają kryteriom [9]:

- zawartość wilgoci $<50 \%$,

- zawartość części palnych > 25\%,

- zawartość substancji niepalnych $<60 \%$.

Celem niniejszej publikacji jest określenie efektywności energetycznej polskich instalacji termicznego przekształcania odpadów komunalnych, poprzez porównanie współczynnika efektywności energetycznej instalacji w Krakowie oraz Białymstoku. Są to dwie z sześciu instalacji termicznego przekształcania odpadów, które powstały w latach 2015-2016. Krakowska spalarnia jest największą, a białostocka jedną z najmniejszych. 


\section{THERMAL TREATMENT PLANTS FOR MUNICIPAL WASTE IN KRAKÓW AND BIALYSTOK - A COMPARISON}

The Waste Thermal Treatment Plant in Krakow (ZTPO) and the Municipal Waste Utilization Plant in Białystok (ZUOK) were established at the same time, that is at the beginning of the second decade of the 21 st century, and in the same legal, economic and social conditions. Therefore, the differences between the plants are small and concern only detailed solutions of their functioning depending on the efficiency of the installation (table 2).

\section{ZAKŁADY TERMICZNEGO PRZEKSZTALCANIA ODPADÓW KOMUNALNYCH W KRAKOWIE I BIAŁYMSTOKU - PORÓWNANIE}

Zakład Termicznego Przekształcania Odpadów w Krakowie (ZTPO) oraz Zakład Unieszkodliwiania Odpadów Komunalnych w Białymstoku (ZUOK) powstawały w tym samym czasie, to jest na początku drugiej dekady XXI wieku, a także w tych samych warunkach prawnych, gospodarczych i społecznych. Dlatego różnice między zakładami są niewielkie i dotyczą tylko szczegółowych rozwiązań ich funkcjonowania w zależności m.in. od wydajności instalacji (tab. 2).

Table 2. Characteristics of the installation of thermal treatment of municipal waste in Kraków and Bialystok [5, 10] Tabela 2. Charakterystyka instalacji termicznego przekształcania odpadów komunalnych w Krakowie i Biatymstoku, opracowanie na podstawie [5, 10]

\begin{tabular}{|c|c|c|c|}
\hline Parameter & Unit & ZTPO Kraków & ZUOK Białystok \\
\hline Number of served inhabitants & Mk & 762400 & 399080 \\
\hline Nominal efficiency of one thermal transformation line & $\mathrm{Mg} / \mathrm{h}$ & 14.1 & 15.5 \\
\hline The number of thermal transformation lines & pcs. & 2 & 1 \\
\hline Nominal plant performance & $\mathrm{Mg} / \mathrm{h}$ & 28.2 & 15.5 \\
\hline Annual plant performance & $\mathrm{Mg} / \mathrm{a}$ & 220000 & 120000 \\
\hline The nominal calorific value of waste & $\mathrm{MJ} / \mathrm{kg}$ & 8.8 & 7.5 \\
\hline Efficiency of the slag valuation installation & $\mathrm{Mg} / \mathrm{a}$ & 66000 & 36500 \\
\hline Efficiency of solidification and chemical stabilization installations for dust and solid residues from flue gas cleaning & $\mathrm{Mg} / \mathrm{a}$ & 11300 & 8600 \\
\hline Ratio of the mass of post-process waste to the mass of recycled municipal waste & $\%$ & 35.14 & 37.58 \\
\hline Combustion temperature in the after-burning chamber & $O C$ & 850 & 860 \\
\hline Thermal energy produced & MWht & 280000 & 100000 \\
\hline Produced electricity & MWhe & 65000 & 38000 \\
\hline $\begin{array}{l}\text { Energy production in cogeneration mode: } \\
\text { - thermal energy } \\
\text { - electricity }\end{array}$ & $\begin{array}{l}\text { MWt } \\
\text { MWe }\end{array}$ & $\begin{array}{l}35 \\
8.7\end{array}$ & $\begin{array}{l}17,5 \\
6.08\end{array}$ \\
\hline Electricity production in condensation mode & MWe & 16.8 & 8.68 \\
\hline Temperature of superheated steam supplied to the municipal heating network during the heating season & ${ }^{\circ} \mathrm{C}$ & 135 & 120 \\
\hline The temperature of water supplied to the municipal heating network outside the heating season & ${ }^{\circ} \mathrm{C}$ & 75 & 70 \\
\hline
\end{tabular}

Both plants accept mixed municipal waste and flammable waste from the sorting plant. In practice, the installations are adapted to transform the same types of waste.The process of accepting the waste looks very similar. The only difference is due to the size of the plants, which is primarily determined by the number of residents served. WTTP in Krakow serves an area inhabited by 762.400 people, and ZUOK in Białystok by 399.080 people (table 2).

Due to the difference in plant capacity, the waste reception hall in Krakow is larger. There are six unloading stations on it, while in Bialystok four such positions are sufficient. However, the bunker in which the waste is mixed before the combustion process is bigger in Bialystok. It provides waste for seven days.
Oba zakłady przyjmują zmieszane odpady komunalne oraz odpady palne $\mathrm{z}$ sortowni. W praktyce instalacje są dostosowane do przekształcania tych samych rodzajów odpadów. Proces przyjęcia odpadów wygląda bardzo podobnie. Jedyna różnica jest spowodowana wielkością zakładów, którą warunkuje przede wszystkim liczba obsługiwanych mieszkańców. ZTPO w Krakowie obsługuje obszar zamieszkany przez 762400 osób, a ZUOK w Białymstoku przez 399080 osób (tab. 2).

$\mathrm{Z}$ powodu różnicy przepustowości zakładów hala przyjęcia odpadów w Krakowie jest większa. Znajduje się na niej sześć stanowisk wyładowczych, podczas gdy w Białymstoku wystarczają cztery takie stanowiska. Natomiast bunkier, w którym mieszane są odpady 
The Krakow bunker provides waste for five days of the incinerator's work.

Systems preventing the uncontrolled emission of dust and odors in the discussed cases are identical. The air from the unloading hall and from the bunker is sucked in and directed to the combustion chamber as the primary air. Fire-fighting activities in both installations consist in continuous mixing of waste in the bunker and constant monitoring of the bunker's interior with a thermal imaging camera.

The supply of waste to the grate takes place in the described installations in the same way. The waste is fed into the hopper, from where they move into the depth of the loading shaft. Its lower part is protected against overheating by a water jacket. Installations differ in the distribution of waste on the grate and the design of the grate itself. In ZUOK in Białystok, a stepped grate, inclined, cooled with air was used. The distribution of waste on the grate provides a hydraulic waste ejector that pushes a specific volume of waste to the grate. From the grate, the waste rolls down the steps creating an even layer of waste on the whole surface of the grate. ZTPO in Krakow is equipped with a grate with hydraulic drive, divided into three sections. The first two are a reciprocating grate with a slope of $10^{\circ}$, the third is a horizontal sliding grate. Waste on the grate goes with a piston feeder, responsible for the appropriate distribution of waste on the grate. Next, the waste is moved by rows of movable grates, alternating with solid grates $[5,10,11]$.

Waste transformed in installations is assumed to have a content of halogenated organic compounds converted into chlorine below $1 \%$, therefore the minimum combustion temperature is $850^{\circ} \mathrm{C}$. In order to obtain and maintain this temperature while the waste is in the combustion chamber, start-up burners have been installed, the heating medium is fuel oil. The booster burners work only when starting and shutting down the plant, as well as during rare cases of reduced calorific value of the waste. Slag and furnace ash produced in the discussed installations are directed from the grate to the wet slag trap. In the slag relief tank, they are cooled before transport to the place where they will be prepared for further development.

Both plants have recovery boilers integrated with the grate, in which the passage of heat from fumes into the water flowing through the boiler's ducts The water vapor in the pipelines of the Krakow installation reaches a temperature of $415^{\circ} \mathrm{C}$ and przed procesem spalania, jest większy w Białymstoku. Zapewnia on zapas odpadów na okres siedmiu dni. Krakowski bunkier zapewnia zapas odpadów na pięć dni pracy spalarni.

Systemy zapobiegania niekontrolowanej emisji pyłów i odorów w omawianych przypadkach są identyczne. Powietrze z hali rozładunkowej oraz znad bunkra jest zasysane i kierowane do komory spalania jako powietrze pierwotne. Działania przeciwpożarowe w obu instalacjach polegają na ciągłym mieszaniu odpadów w bunkrze oraz stałym monitorowaniu wnętrza bunkra za pomocą kamery termowizyjnej.

Podaż odpadów na ruszt przebiega w opisywanych instalacjach tak samo. Odpady podawane są do leja zasypowego, skąd przemieszczają się w głąb szybu załadowczego. Jego dolna część jest chroniona przed przegrzaniem płaszczem wodnym. Instalacje różnią się rozmieszczeniem odpadów na ruszcie oraz konstrukcją samego rusztu. W ZUOK w Białymstoku zastosowano ruszt schodkowy, pochylony, chłodzony powietrzem. Rozłożenie odpadów na ruszcie zapewnia hydrauliczny wypychacz odpadów, wypychający określoną objętość odpadów na ruszt. Z rusztu odpady staczają się po schodkach, tworząc równą warstwę odpadów na całej powierzchni rusztu. ZTPO w Krakowie wyposażony jest $\mathrm{w}$ ruszt $\mathrm{z}$ napędem hydraulicznym, podzielonym na trzy sekcje. Pierwsze dwie to ruszt posuwisto-zwrotny o nachyleniu $10^{\circ}$, trzecia to ruszt posuwisty poziomy. Odpady na ruszt trafiają przy pomocy podajnika tłokowego, odpowiadającego za odpowiednie rozmieszczenie odpadów na ruszcie. Dalej odpady przemieszczane są przez rzędy ruchomych rusztowin, rozmieszczonych naprzemiennie $\mathrm{z}$ rusztowinami stałymi $[5,10,11]$.

Odpady przekształcane $\mathrm{w}$ instalacjach $\mathrm{z}$ założenia mają zawartość związków chlorowcoorganicznych przeliczonych na chlor poniżej $1 \%$, dlatego minimalna temperatura spalania wynosi $850^{\circ} \mathrm{C}$. W celu uzyskania i utrzymania tej temperatury w czasie przebywania odpadów w komorze spalania zainstalowano palniki rozruchowo-wspomagające, medium wspomagającym spalanie jest olej opałowy. Palniki rozruchowo-wspomagające pracują tylko podczas rozruchu i wyłączania instalacji, a także podczas rzadkich przypadków obniżonej kaloryczności odpadów. Żużel oraz popiół paleniskowy powstające $\mathrm{w}$ omawianych instalacjach, kierowane są z rusztu do mokrego odżużlacza. W odżużlaczu następuje ich schłodzenie przed transportem do miejsca, w którym będą przygotowane do dalszego zagospodarowania.

Oba zakłady posiadają kotły odzysknicowe zintegrowane z rusztem, w których zachodzi przejście 
a pressure of 40 bar, in Bialystok the temperature is $400^{\circ} \mathrm{C}$ and the pressure is 40 bar. Overheated steam goes to a condensing-bleeder turbine, which in turn drives a generator transforming mechanical energy into electricity. The plant in Bialystok normally works in cogeneration mode. During this time, it produces $6.08 \mathrm{MWe}$ electricity and 17.50 MWt heat energy (Table 2). The plant in Kraków in the cogeneration mode produces electricity with the capacity of 8.7 MWe and heat energy with a capacity of $35 \mathrm{MWt}$. In the condensation mode (generation of only electric energy), 8.68 MWe electricity is produced in Białystok. In Kraków, 16.8 MWe of energy is produced in this mode (Table 2).

\section{CALCULATION OF THE ENERGY EFFICIENCY COEFFICIENT FOR INSTALLATIONS IN KRAKÓW AND BIALYSTOK}

The energy efficiency ratio of a waste thermal treatment installation that has been authorized since December 31, 2008 must be at least 0.65 [1]. The energy efficiency coefficient is described by the formula [1]:

where:

$$
E=\frac{E_{p}-E_{f}-E_{i}}{0.97 \cdot\left(E_{w}+E_{f}\right)}[-]
$$

$E_{p}$ - the amount of energy produced annually as thermal or electric energy (MWh),

$E_{f}$ - annual energy input to the system from the combustion of fuels involved in the production of steam (MWh).

$E_{w}$ - annual amount of energy supplied with fuel, calculated as the product )of the lower calorific value of waste and the annual mass of waste processed (MWh),

$E_{i}$ - annual energy input from outside excluding $E_{w}$ i $E_{f}(M W h)$,

0.97 - coefficient taking into account energy losses by bottom ash and radiation.

The value of energy produced nominally $\left(E_{p}\right)$ calculated on the basis of the formula [1]:

$$
E_{p}=1.1 \cdot E_{t}+2.6 \cdot E_{e l}[\mathrm{MWh}]
$$

where:

$E_{t}-$ annually produced amount of thermal energy in the plant [MWht], ciepła ze spalin do wody przepływającej przez przewody kotła. Para wodna w przewodach krakowskiej instalacji osiąga temperaturę $415^{\circ} \mathrm{C}$ i ciśnienie 40 bar, w Białymstoku temperaturę $400^{\circ} \mathrm{C}$ i ciśnienie 40 bar. Przegrzana para trafia do turbiny kondensacyjno-upustowej, która z kolei napędza generator przekształcający energię mechaniczną w elektryczną. Zakład w Białymstoku pracuje w trybie kogeneracji. W tym czasie wytwarza energię elektryczną o mocy 6,08 MWe i energię cieplną o mocy 17,50 MWt (tab. 2) Zakład w Krakowie w trybie kogeneracji produkuje energię o mocy 8,7 MWe i energię cieplną o mocy 35 MWt. W trybie kondensacji (wytwarzanie samej energii elektrycznej) w Białymstoku produkowana jest energia elektryczna o mocy 8,68 MWe. W Krakowie w tym trybie produkowana jest energia o mocy 16,8 MWe (tab. 2).

\section{OBLICZENIE WSPÓŁCZYNNIKA EFEKTYWNOŚCI ENERGETYCZNE DLA INSTALACJI W KRAKOWIE I BIAŁYMSTOKU}

Współczynnik efektywności energetycznej instalacji termicznego przekształcania odpadów, które otrzymały zezwolenie po 31 grudnia 2008 roku musi wynosić co najmniej 0,65 [1]. Współczynnik efektywności energetycznej opisany jest wzorem [1]:

gdzie:

$$
E=\frac{E_{p}-E_{f}-E_{i}}{0.97 \cdot\left(E_{w}+E_{f}\right)}[-]
$$

$E_{p}$ - ilość energii produkowanej rocznie jako energia cieplna lub elektryczna (MWh),

$\mathrm{E}_{\mathrm{f}}-$ ilość energii wprowadzanej rocznie do systemu, pochodząca ze spalania paliw biorących udział w wytwarzaniu pary (MWh),

$E_{w}$ - roczna ilość energii dostarczanej z paliwem, obliczana jako iloczyn dolnej wartości opałowej odpadów oraz rocznej masy przetwarzanych odpadów (MWh),

$E_{i}$ - roczna ilość energii wprowadzana z zewnątrz z wyłączeniem $E_{w}$ i $E_{f}(\mathrm{MWh})$,

0,97-współczynnik uwzględniający straty energii przez popiół denny i promieniowanie.

Wartość energii produkowanej nominalnie $\left(E_{\mathrm{p}}\right)$ obliczana na podstawie wzoru [1]:

$$
E_{p}=1.1 \cdot E_{t}+2.6 \cdot E_{e l}[\mathrm{MWh}]
$$

gdzie:

$E_{t}-$ rocznie produkowana ilość energii cieplnej w zakładzie [MWht], 
$E_{e l}$ - annually produced amount of electricity in the plant [MWhe],

1.1 - coefficient increasing for thermal energy produced, amortizing loss in processing $[-]$,

2.6 - increasing coefficient for the electricity produced, amortizing loss in the processing $[-]$.

The amount of energy $\left(E_{w}\right)$ introduced into the installation, and contained in the processed waste, is calculated by the formula [1]:

$$
E_{w}=\frac{V_{w} \cdot Q_{w}}{3} 3.6[\mathrm{MWh}]
$$

where:

$V_{m}$ - nominal annual mass of waste processed $[\mathrm{Mg}]$,

$Q_{w}$ - nominal calorific value of waste $[\mathrm{GJ} / \mathrm{Mg}]$,

3,6 - conversion factor GJ per MWh [GJ/MWh].

Unit values of coefficients $E_{f}$ and $E_{i}$ in this paper adopted on the basis of the document Results of Specific Data for Energy, Efficiency Rates and Coefficients, Plant Efficiency factors and NCV of 97 European W-t-E Plants and Determination of the Main Energy Results elaborated by D.O. Reimanna for the needs of the organization Confederation of European Waste-to-Energy Plants (CEWEP). According to the document, the average unit value $E_{f i}$ is $0.023 \mathrm{MWh} /$ $\mathrm{Mg}$, while the average unit value $E_{i j}$ is $0.055 \mathrm{MWh} /$ $\mathrm{Mg}$ [11].

The amount of energy introduced into the system, coming from the combustion of fuels taking part in steam generation $\left(E_{f}\right)$ is calculated on the basis of formula [1]:

$$
E_{f}=E_{f j} \cdot V_{m}[\mathrm{MWh}]
$$

where:

$E_{f j}$ - unit energy factor introduced into the system, derived from the combustion of fuels involved in steam generation, assumed value of 0.023 $\mathrm{MWh} / \mathrm{Mg}$,

$V_{m}$ - nominal annual mass of waste processed $[\mathrm{Mg}]$.

The annual amount of energy introduced from outside $\left(E_{i}\right)$ is calculated on the basis of formula [1]:

$$
E_{i}=E_{i j} \cdot V_{m}[\mathrm{MWh}]
$$

$E_{e l}$ - rocznie produkowana ilość energii elektrycznej w zakładzie [MWhe],

1,1 - wzrost współczynnika dla wytworzonej energii cieplnej, amortyzacja strat w przetwarzaniu [-]

2,6 - zwiększenie współczynnika produkowanej energii elektrycznej, amortyzacja strat w przetwarzaniu $[-]$.

Ilość energii $\left(E_{w}\right)$ wprowadzanej do instalacji, a zawartej $\mathrm{w}$ przetwarzanych odpadach, obliczana jest wzorem [1]:

$$
E_{w}=\frac{V_{w} \cdot Q_{w}}{3} 3,6[\mathrm{MWh}]
$$

gdzie:

$V_{m}$ - nominalna roczna masa przetwarzanych odpadów $[\mathrm{Mg}]$,

$Q_{w}$ - nominalna wartość opałowa odpadów [GJ/Mg], 3,6 - współczynnik przeliczeniowy GJ na MWh.

Wartości jednostkowych współczynników $E_{f}$ oraz $E_{i}$ przyjęto na podstawie dokumentu Results of Specific Data for Energy, Efficiency Rates and Coefficients, Plant Efficiency factors and NCV of $97 \mathrm{Eu}-$ ropean W-t-E Plants and Determination of the Main Energy Results opracowanego przez D.O. Reimanna na potrzeby organizacji Confederation of European Waste-to-Energy Plants (CEWEP). Według dokumentu średnia wartość jednostkowa $E_{f j}$ wynosi 0,023 $\mathrm{MWh} / \mathrm{Mg}$, natomiast średnia wartość jednostkowa $E_{i j}$ to $0,055 \mathrm{MWh} / \mathrm{Mg}$ [11].

Ilość energii wprowadzanej do systemu, pochodząca ze spalania paliw biorących udział w wytwarzaniu pary $\left(E_{f}\right)$, obliczana jest na podstawie wzoru [1]:

$$
E_{f}=E_{f j} \cdot V_{m}[\mathrm{MWh}]
$$

gdzie:

$E_{f j}$ - jednostkowy współczynnik energii wprowadzanej do systemu, pochodzącej ze spalania paliw biorących udział w wytwarzaniu pary, przyjmowana wartość $0,023 \mathrm{MWh} / \mathrm{Mg}$,

$V_{m}$ - nominalna roczna masa przetwarzanych odpadów $[\mathrm{Mg}]$.

Roczna ilość energii z wyłączeniem $E_{w}$ i $E_{f}$ wprowadzana z zewnątrz $\left(E_{i}\right)$ obliczana jest na podstawie wzoru [1]:

$$
E_{i}=E_{i j} \cdot V_{m}[\mathrm{MWh}]
$$


where:

$E_{i}$ - unit energy factor introduced from outside excluding $E_{w}$ i $E_{f}$, assumed value 0.055 [MWh/ $\mathrm{Mg}$,

$V_{m}$ - nominal annual mass of waste processed $[\mathrm{Mg}]$.

The condensation mode is assumed only if there is no possibility of returning heat energy to the district heating network, for example during a transmission network failure. In the course of continuous operation in the condensation mode, during the year, electricity production would reach the level represented by the formula [1]:

$$
E_{e l}=P \cdot t_{n o m}[\mathrm{MWh}]
$$

where:

$P$ - electric power produced by the plant in condensation mode,

$t_{\text {nom }}$ - nominal operating time of the installation during the year (for both installations, the nominal working time during the year equals $7.800 \mathrm{~h}$ ).

Calculations of the energy efficiency coefficient are presented in Table 3. The calculations were made using theoretical assumptions, which were adopted on the basis of data from environmental reports $[6,12]$.

\begin{tabular}{|c|c|c|}
\hline Parameter & ZTPO Kraków & ZTPO Białystok \\
\hline \multicolumn{3}{|c|}{ Co-generation mode } \\
\hline$E_{p}$ & $477000 \mathrm{MWh}$ & $208800 \mathrm{MWh}$ \\
\hline$E_{w}$ & $537778 \mathrm{MWh}$ & $250000 \mathrm{MWh}$ \\
\hline$E_{f}$ & $5060 \mathrm{MWh}$ & $2760 \mathrm{MWh}$ \\
\hline$E_{i}$ & $12100 \mathrm{MWh}$ & $6600 \mathrm{MWh}$ \\
\hline$E$ & 0.873 & $0.813]$ \\
\hline \multicolumn{3}{|c|}{ Condensation mode } \\
\hline$E_{e l}$ & $131040 \mathrm{MWh}$ & $67704 \mathrm{MWh}$ \\
\hline$E_{p}$ & $340704 \mathrm{MWh}$ & $176030 \mathrm{MWh}$ \\
\hline$E_{k}$ & 0.614 & 0.680 \\
\hline
\end{tabular}

ZUOK Białystok meets the requirements of the Waste Act regardless of the operating mode. Higher efficiency was obtained in the variant of work in cogeneration mode (Table 3). ZTPO in Krakow, when operating in the condensation mode, does not meet the value of the combustion efficiency factor of 0.65 gdzie:

$E_{i}$ - jednostkowy współczynnik energii wprowadzanej z zewnątrz z wyłączeniem $E_{w}$ i $E_{f}$ przyjmowana wartość $0,055[\mathrm{MWh} / \mathrm{Mg}$ ],

$V_{m}$ - nominalna roczna masa przetwarzanych odpadów $[\mathrm{Mg}]$.

Tryb kondensacji z założenia jest stosowany tylko w przypadku braku możliwości oddawania energii cieplnej do miejskiej sieci ciepłowniczej, na przykład podczas awarii sieci przesyłowej. Przy ciągłej pracy $\mathrm{w}$ trybie kondensacji, w ciągu roku produkcja energii elektrycznej osiągnęlaby poziom przedstawiony wzorem [1]:

$$
E_{\text {el }}=P \cdot t_{\text {nom }}[\mathrm{MWh}]
$$

gdzie:

$P$ - moc elektryczna produkowana przez zakład w trybie kondensacji,

$t_{\text {nom }}$ - nominalny czas pracy instalacji w ciągu roku (dla obu instalacji nominalny czas pracy w ciągu roku równa się 7800 h).

Obliczenia współczynnika efektywności energetycznej przedstawiono w tabeli 3. Obliczenia wykonano wykorzystując założenia teoretyczne, które przyjęto na podstawie danych pochodzących $\mathrm{z}$ raportów środowiskowych $[6,12]$.

Table 3. Energy efficiency coefficient for municipal waste thermal treatment installations in Krakow and Bialystok Tabela 3. Wspótczynnik efektywności energetycznej instalacji termicznego przetwarzania odpadów komunalnych w Krakowie i Białymstoku

ZUOK Białystok spełnia wymagania Ustawy o odpadach niezależnie od trybu pracy. Wyższą efektywność otrzymano w wariancie pracy w trybie kogeneracji (tab. 3). ZTPO w Krakowie, podczas pracy w trybie kondensacji nie spełnia wymaganej w Ustawie o odpadach wartości współczynnika efektywności spalarni 
as required by the Waste Act. However, operation in condensation mode for both incineration plants is only envisaged if the heat can not be transferred to the district heating network, eg in the case of technical inspections of the network or failure. Most of the time, both installations work in cogeneration mode.

\section{SUMMARY AND CONCLUSIONS}

Due to EU obligations, according to which Poland must reduce the amount of biodegradable waste going to landfills by 16 July 2020 , solutions such as thermal waste treatment installations are justified and will be constantly developed. The contemporary approach to waste management, if possible, puts the first priority in recovery, and only then in the second place disposal. The installations for thermal waste treatment compared in the article do not differ significantly in work parameters. They are adapted to transform the same types of waste. The differences concern the efficiency of plants and the amount of energy produced. Differences are caused by the different number of residents served and, consequently, by the number of thermal transformation lines. The article presents a computational course for determining the energy efficiency coefficient. The energy efficiency coefficient takes into account the amount of thermal and electrical energy produced by the plant during the year, the mass and calorific value of the waste, as well as the operating mode of the plant. In the case of both installations of thermal treatment of municipal waste, the energy efficiency coefficient values obtained meet the requirements of the abovementioned Act. Despite differences in installation efficiency, both plants achieve similar values of the energy efficiency ratio wynoszącego 0,65 . Jednak praca w trybie kondensacji w przypadku obu spalarni jest przewidywana tylko w razie braku możliwości oddawania energii cieplnej do miejskiej sieci ciepłowniczej, np. w przypadku przeglądów technicznych sieci czy awarii. Przez zdecydowaną większość czasu obie instalacje pracują w trybie kogeneracji.

\section{PODSUMOWANIE I WNIOSKI}

Ze względu na unijne zobowiązania, według których Polska musi do 16 lipca 2020 roku ograniczyć ilość odpadów biodegradowalnych trafiających na składowiska, rozwiązania takie jak instalacje termicznego przetwarzania odpadów są uzasadnione i będą stale rozwijane. Współczesne podejście do gospodarki odpadami, jeśli jest to możliwe, na pierwszym miejscu stawia odzysk, natomiast dopiero w dalszej kolejności unieszkodliwianie. Porównywane w artykule instalacje termicznego przetwarzania odpadów nie różnią się znacząco parametrami pracy. Są dostosowane do przekształcania tych samych rodzajów odpadów. Różnice dotyczą wydajności zakładów oraz ilości produkowanej energii. Różnice spowodowane są różną liczbą obsługiwanych mieszkańców, a w konsekwencji liczbą linii termicznego przekształcania. W artykule przedstawiono tok obliczeniowy wyznaczania współczynnika efektywności energetycznej. Współczynnik efektywności energetycznej uwzględnia ilość energii cieplnej i elektrycznej produkowanej przez zakład w ciągu roku, masę oraz wartość opałową odpadów, jak również tryb pracy zakładu. W przypadkach obydwu instalacji termicznego przetwarzania odpadów komunalnych otrzymane wartości współczynnika efektywności energetycznej spełniają wymagania wyżej wymienionej ustawy. Pomimo różnic wydajności instalacji obydwa zakłady osiągają zbliżone wartości współczynnika efektywności energetycznej.

\section{REFERENCES}

[1] Ustawa z dnia 14 grudnia 2012 roku o odpadach (Dz.U. 2013, poz. 21), z późniejszymi zmianami.

[2] Dyrektywa Parlamentu Europejskiego i Rady 2008/98/WE w sprawie odpadów oraz uchylającej niektóre dyrektywy, Dz.U. L 312 z 22.11.2008.

[3] Małyska P.: Analiza ilościowa strumieni odpadów komunalnych wytwarzanych $w$ Polsce oraz prawne i rynkowe możliwości ich utylizacji w spalarniach - perspektywa 2020, Rynek Energii, 2016, Nr 3 (124), s. 81-88.

[4] Wielgosiński G.: Wybór technologii termicznego przeksztatcania odpadów komunalnych, Nowa Energia - nr 1/2012, s. $1-17$.

[5] Materiały niepublikowane, ZUOK Białystok 2017.

[6] Raport o oddziaływaniu przedsięwzięcia na środowisko dla przedsięwzięcia pt: „Budowa Zakładu Unieszkodliwiania Odpadów Komunalnych w Biatymstoku", 2009.

[7] Kinitz N.: Budujemy petna para. Raport. Spalarnie w Polsce, Przegląd komunalny,nr 9/2014, s. 10-14.

[8] Wandrasz J.W., Wandrasz A.J.: Paliwa formowane. Biopaliwa i paliwa z odpadów w procesach termicznych. w yd. Seidel.Przywecki. 2006. 
[9] Żygadło M.: Strategia gospodarki odpadami komunalnymi. Wyd. PZiTS. Poznań. 2001.

[10] Materiały niepublikowane, ZTPO Kraków 2017.

[11] Reimann D.O., Results of Specific Data for Energy, Efficiency Rates and Coefficients, Plant Efficiency factors and NCV of 97 European W-t-E Plants and Determination of the Main Energy Results, Bamberg 2006.

[12] Raport o oddziaływaniu na środowisko dla przedsięwzięcia: „Budowa Zakładu Termicznego Przeksztatcania Odpadów przy ul. Giedroycia w Krakowie” jako element projektu „Program gospodarki odpadami komunalnymi w Krakowie", Warszawa 2009.

\section{Acknowledgments:}

The work was financed by Kielce University of Technology part of the statutory work No.

05.0.09.00/2.01.01.01.0003 MNSP.IKGO.17.003

\section{Podziękowania}

Praca była finansowana przez Politechnikę Świętokrzyska w ramach pracy statutowej $n r$ :

05.0.09.00/2.01.01.01.0003 MNSP.IKGO.17.003 